\title{
Analysis of skull morphometric characters in Owls (Strigiformes)
}

\author{
Tibor PeCsics ${ }^{1}$, Miklós LACZI ${ }^{1,3}$, Gergely NAGY ${ }^{1}$, Tamás KondoR ${ }^{1}$ \\ \& Tibor CsÖRGÖ ${ }^{2}$
}

Received: April 3, 2018 -Revised: June 16, 2018 -Accepted: June 25, 2018

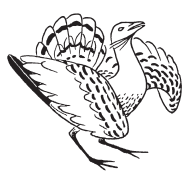

Pecsics, T., Laczi, M., Nagy, G., Kondor, T. \& Csörgő, T. 2018. Analysis of skull morphometric characters in Owls (Strigiformes). - Ornis Hungarica 26(1): DOI: 41-53. 10.1515/orhu-2018-0003

Abstract Owls (Strigiformes) are small to large birds, mostly solitary and nocturnal predators. They can be found all around the Earth except Antarctica and some remote islands. The species differ in size, diet and habitat, which led to different morphological adaptations of the skull. The main differences are in the orbital and the otical region, which are connected to the visual and hearing capabilities. The aim of the recent study is to increase our knowledge of the relationship between skull shape and foraging habits and tried to find those characters that are related to diet. A geometric morphometric approach was used to analyse two-dimensional cranial landmarks. We used principal component (PC) analyses on measurements that may be related to visual and hearing abilities. The PCs are resulted in the robusticity of the skull and the asymmetry of the otical region. There are differences in position and shape of postorbital processes (POP) and tympanic wings (TW). Species with symmetrical skull shape are basically crepuscular or diurnal predators and species with more asymmetrical skulls are mostly nocturnal hunters and have better hearing capabilities.

Keywords: cranial morphology, morphometrics, anatomy, nocturnal predator, prey preference

Összefoglalás A baglyok közé (Strigiformes) kis- és nagytestü fajok egyaránt tartoznak. Többnyire magányos éjszakai ragadozók. Világszerte megtalálhatóak az Antarktisz és néhány távoli sziget kivételével. A fajok különböznek méretüket, táplálékbázisukat és táplálékszerzésüket tekintve, mindezek a koponyán is morfológiai adaptációt mutatnak. A legföbb különbségek az orbitalis és oticalis régióhoz köthetők, amelyek elsősorban látással és hallással kapcsolatos képességekkel mutatnak összefüggést. Jelen cikkben a baglyok cranialis jegyeinek elemzésével a táplálékpreferencia, a táplálékszerzés és a morfológiai jellemzők közötti lehetséges kapcsolatokat kerestük. A craniomorfometriai vizsgálat során kétdimenziós landmarkok használatával főkomponens-analíziseket végeztünk. A főkomponensek a koponya robuszticitásával és a koponya oticalis régiójának aszimmetriájával hozhatók kapcsolatba. Különbségek vannak a processus postorbitalisok (POP) és halántékcsont tympanicus nyúlványainak (TW) helyzetében és alakjában. Azok a fajok, amelyek szimmetrikus koponyával rendelkeznek, többnyire nappali vagy alkonyati ragadozók, szemben az aszimmetrikus koponyájú fajokkal, amelyek leginkább éjszaka aktívak és jobb hallási képességekkel rendelkeznek.

Kulcsszavak: koponya-sajátosságok, morfometria, anatómia, éjszakai ragadozó, táplálék-összetétel, táplálékpreferencia

\footnotetext{
${ }^{1}$ Behavioural Ecology Group, Department of Systematic Zoology and Ecology, Eötvös Loránd University, 1117 Budapest, Pázmány Péter sétány 1/C, Hungary,e-mail: nobilis.equus@gmail.com ${ }^{2}$ Department of Anatomy, Cell- and Developmental Biology, Eötvös Loránd University, 1117 Budapest, Pázmány Péter sétány $1 / C$, Hungary

${ }^{3}$ The Barn Owl Foundation, 8744 Orosztony, Temesvári út 8., Hungary

*corresponding author
} 


\section{Introduction}

Owls are small to large predators; mostly solitary and nocturnal or crepuscular. The group is globally distributed, except the Antarctica and some remote islands. The order Strigiformes is divided into 2 families, Tytonidae (barn owls and allies) and Strigidae (true owls) (Cramp 1978). Owls are sharing similar anatomical characteristics with the diurnal raptors like sharp hooked beak and talons. Due to these similarities owls were closely related to falcons (Cracraft 1981), but some authors supported the view, that these birds are closer relatives of nightjars (Caprimulgiformes) (Mayr \& Amadon 1951, Sibley \& Ahlquist 1990). Recent studies have provided good evidence, that diurnal raptors are closer relatives of owls than nightjars (Ericson et al. 2006, Hackett et al. 2008, Wink et al. 2009, Brusatte et al. 2015). The anatomical similarities between owls and nightjars are probably influenced by convergence (Feduccia 1996).

The barn owls (Tytonidae) comprise 2 extant genera around 20 species (Aliabadian et al. 2016, Uva et al. 2018), the true owls (Strigidae) comprise around 190 species in 25 genera (Wink et al. 2008).

Features are common to both families. Eyes directed forwards. Bills hooked as in Falconiformes, but directed more downwards. Base of bill with soft cere is similar to Falconiformes, but covered by bristles projecting laterally from base of bill. Outer toe is reversible, but directed laterally at rest. In some species, erectile ear-like tufts of feathers are visible on forehead (Cramp 1978). Owls are generally active at night and have a highly developed auditory system. The ears are covered by the feathers of the facial disc. Some species have asymmetrically set ear openings and a very pronounced facial disc, guiding sounds into the ear openings. The shape of the disc can be modulated with special facial muscles. The bill is pointed downward, increasing the surface area over which the soundwaves are collected by the facial disc (Nishikawa 2002). The translation of left, right, up and down signals are combined in the brain, and create an image of the space where the sound source is located. Studies of owl brains have revealed that the medulla is more complex than in other birds (Dyson et al. 1998). These factors have strong effect on the skeletal structure of the head.

In most avian lineages, male-male competition for females has led to an increase in male size due to sexual selection, therefore the males are larger than females (Andersson 1994, Colwell 2000). However, in some groups like raptors and owls, reversed size dimorphism exists, which means that females are the larger sex (Mueller 1990, Owens \& Hartley 1998). In owls, the results showed clear parallels. Reversed sexual dimorphism (RSD) increases with prey size, consistent with the small-male hypothesis. Evolutionary pathway analysis suggests that RSD in owls has most likely evolved before specialisation on large prey, so a small and more agile male might be advantageous even when hunting small prey. These results suggest that RSD in owls evolved due to natural-selection pressures rather than sexual-selection pressures (Krüger 2005). The intrasexual dimorphism is visible in the case of number of vertebrate taxa. However, morphological differences in shape between males and females are undetectable (Verwaijen et al. 2002).

In the recent study, our objective was to increase our knowledge on the relationship between skull shape and foraging habits, and to find those characters that are related to diet. 


\section{Materials and methods}

\section{Specimens}

This study is based on 42 skulls of 25 species (Table 1). All skulls are from adult specimens and belonging to the collection of Eötvös Loránd University (Budapest, Hungary), the collection of the Hungarian Natural History Museum and the digital archive of Wageningen University (Wageningen, Netherlands). No birds has been killed to get its skull, all birds died of natural causes or accidental or died in captivity.

Table 1. List of owl species examined in this study

1. táblázat A vizsgálatban szereplő bagolyfajok

\begin{tabular}{|l|l|l|l|}
\hline \multicolumn{1}{|c|}{ Scientific name } & \multicolumn{1}{c|}{ Common name } & $\mathbf{n}$ & Abbrevation \\
\hline Aegolius funereus & Tengmalm's Owl & 1 & aegfun \\
\hline Asio capensis & African Marsh Owl & 1 & asicap \\
\hline Asio flammeus & Short-eared Owl & 3 & asifla \\
\hline Asio otus & Long-eared Owl & 3 & asiotu \\
\hline Athene brama & Spotted Owlet & 1 & athbra \\
\hline Athene cunicularia & Burrowing Owl & 1 & athcun \\
\hline Athene noctua & Little Owl & 4 & athnoc \\
\hline Bubo africanus & Spotted Eagle Owl & 1 & bubafr \\
\hline Bubo bubo & Eagle Owl & 3 & bubbub \\
\hline Bubo virginianus & Great Horned Owl & 1 & bubvir \\
\hline Glaucidium brasilianum & Ferruginous Pygmy Owl & 1 & glabra \\
\hline Glaucidium passerinum & Eurasian Pygmy Owl & 1 & glapas \\
\hline Glaucidium perlatum & Pearl-spotted Owlet & 1 & glaper \\
\hline Bubo scandiaca & Snowy Owl & 2 & bubsca \\
\hline Otus asio & Eastern Screech Owl & 1 & otuasi \\
\hline Otus brucei & Striated Scops Owl & 1 & otubru \\
\hline Otus kennikottii & Western Screech Owl & 1 & otuken \\
\hline Otus leucotis & White-faced Scops Owl & 1 & otuleu \\
\hline Otus scops & Eurasian Scops Owl & 3 & otusco \\
\hline Strix aluco & Tawny Owl & 1 & stralu \\
\hline Strix nebulosa & Great Grey Owl & strneb \\
\hline Strix uralensis & Ural Owl & strura \\
\hline Strix varia & Barred Owl & strvar \\
\hline Surnia ulula & Northern Hawk Owl & surulu \\
\hline Tyto alba & Barn Owl & tytalb \\
\hline
\end{tabular}




\section{Groups and diet}

Before the analyses, we created three groups, which represent the following diet categories (Earhart \& Johnson 1970). The present study seeks to test also that the different prey preference may have effect on skull morphology.

- A: feeds primarily on arthropods, for example Eurasian Scops Owl (Otus scops) (Kadochnikov 1963, Galeotti \& Sacchi 2001, Lee \& Severinghaus 2004)

- B: species feed on arthropods and vertebrates, for example Little Owl (Athene noctua) (Glue \& Scott 1980, Laursen 1981, Hounsome et al. 2004, Śálek et al. 2013, Hámori et al. 2017), Northern Hawk Owl (Surnia ulula) (Nybo \& Sonerud 1990, Sonerud 1986, 1992).

- C: feeds exclusively on vertebrates, for example Great Eagle Owl (Bubo bubo) (Papageorgiou et al. 1993, Penteriani et al. 2002, Milchev \& Spassov 2017), Barn Owl (Tyto alba) (Milchev 2015, Horváth et al. 2018)

\section{Landmarks and procedures}

The variation of strigiform cranial morphology is analysed using landmark-based geometric morphometry. In our former study, we used conventional morphometric variables which were selected a priori (Pecsics et al. 2017), however in this case (although the landmarks) the meaningful variables are discovered by the analysis. We do not need to decide among them before the analysis. We tried to choose the landmarks for this analysis to cover the geometric form of the skull. The landmarks should provide a comprehensive sampling of morphology that the features of biological significance can be discovered. The discrete and obvious anatomical characters are ideal landmarks, do not alter their topological positions relative to other landmarks, provide adequate coverage of the morphology and can be found repeatedly and reliably (Zelditch et al. 2004). The landmarks were taken from high resolution $(1200 \times 1600$ pixels $)$ photos. We took 2 photographs from each specimen (lateral and dorsal) with closed jaws. Images were standardised for the foramen magnum occipitale and the

Table 2. Number and description of landmarks. Terminology according to (Baumel et al. 1993)

2. táblázat Az egyes landmarkok száma és leírása. Terminológia Baumel et al. (1993) alapján

\begin{tabular}{|c|c|}
\hline $\begin{array}{c}\text { Number of } \\
\text { landmark }\end{array}$ & Description of landmark \\
\hline 1 & tip of the maxilla \\
\hline 2 & upper point of the left nostril \\
\hline 3 & upper point of the right nostril \\
\hline 4 & connection of maxilla and frontale \\
\hline 5 & upper point of the right orbital margin \\
\hline 6 & upper point of the left orbital margin \\
\hline 7 & tip of the right postorbital process \\
\hline 8 & tip of the left postorbital process \\
\hline 9 & inner point of the right postorbital process \\
\hline 10 & inner point of the left postorbital process \\
\hline 11 & tip of right tympanic wing \\
\hline 12 & tip of left tympanic wing \\
\hline 13 & basal point of the right tympanic wing \\
\hline 14 & basal point of the left tympanic wing \\
\hline 15 & lowest point of the occipital bone \\
\hline
\end{tabular}




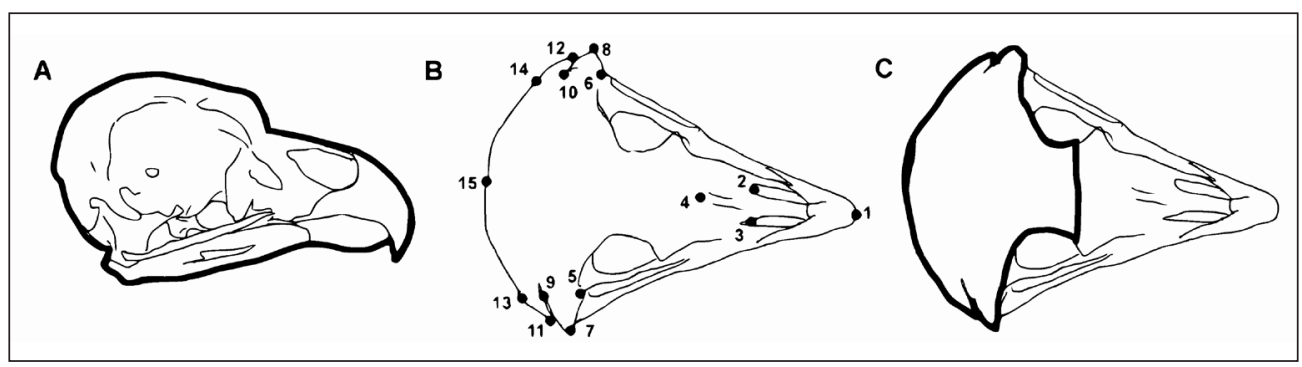

Figure 1. Position and number of landmarks. A: whole skull shape in lateral view, B: fixed landmarks in dorsal view (numbers correspond to Table 2), C: the shape of the neurocranium behind the lacrimal bones in lateral view

1. ábra A vizsgálatban használt landmarkok száma és pozíciója. A: a teljes koponya oldalnézetből, B: fix landmarkok felülnézetből (a számok megnevezését lásd a 2. táblázatban), C: az agykoponya könnycsontok mögötti része felülnézetből

tip of the beak. We investigated the repeatability of the measurements by Speraman's correlation. The test was between two separate digital measures performed on skull photos $(n=$ 20). For each specimen 15 fixed landmarks (Table 2) were recorded in dorsal view and we used 1000 sliding landmarks to examine the shape of the neurocranium in dorsal view and the shape of the whole skull in lateral view (Figure 1). These landmarks were allowed to slide along their corresponding curve, which is necessary in the case of the minimalisation of the bending energy. The coordinates of the landmarks were digitised using TpsDig 2.16 software (Rohlf 2010). The coordinates were transformed using the Procrustes superimposition method. The consensus configurations and relative warps were conducted. Variability in shape was assessed using the scores obtained for each individual on the first two relative warps. We conducted principal component analyses (PCA) on these morphological variables. The relative warps are corresponding to the principal components (PCs) and define the shape space in which individuals are replaced. We used PAST v.1.7 software (Hammer et al. 2001) for principal component analysis and to extract deformation grids. We only considered those PCs which are explaining individually $>10 \%$ of the variance.

\section{Results}

Our measures were highly significant irrespective of measuring mode (all $r>0.98$, all $P<$ $0.00001)$.

The first analysis focused on the whole skull from lateral view (Figure 2). We used sliding landmarks (1000) to describe the shape. The first two PCs explained $49 \%$ and $15 \%$ of the variance in skull shape. The first PC axis described the relative height of the skull and the roundness of the frontal bone (PC1). The second $\mathrm{PC}$ axis described the relative highness of the beak (PC2). The shape of the skull of Barn Owl was found different from that species.

During the second analysis we used 15 fixed landmarks recorded in dorsal view. The first three PCs explained $44 \%, 15 \%$, and $10 \%$ of the variance in shape (Figure 3). The first and second $\mathrm{PC}$ axes described variation in the relative distances of the temporal wing (PC1), and 


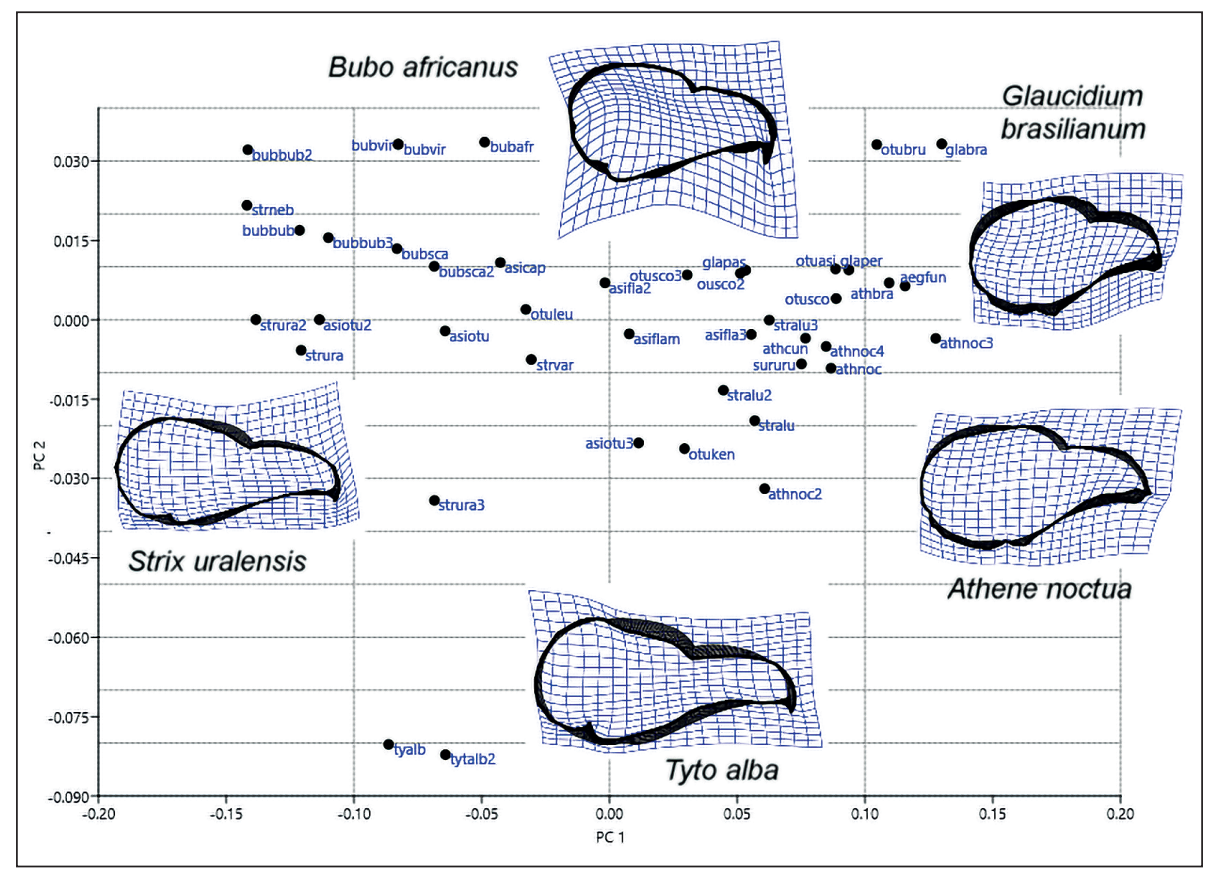

Figure 2. Graphical output of PCA performed on the two-dimensional landmark data (lateral view). PC1PC2 biplot. The first PC axis described the relative height of the skull and the roundness of the frontal bone (PC1). The second PC axis described the relative highness of the beak (PC2). Thick black areas are showing the differences compared to the computer generated mean shape

2. ábra A PCA grafikus megjelenítése kétdimenziós landmark adatok alapján (oldalnézet). Az első főtengely a koponya relatív magasságát és a homlokcsont domborúságát magyarázza (PC1). A második főtengely a csőr relatív magasságával hozható kapcsolatba (PC2). A fekete vastagított terület a komputergenerált átlagformától való eltérést mutatja

the relative orientation at the tip ( $\mathrm{PC} 2$ ) compared to the postorbital processes. The third PC axis described differences in the distance of the tip of the beak (results not shown). In dorsal view, the Little Owl and the Northern Hawk-Owl showed symmetrical shape. Species like Short-eared Owl and Tawny Owl have moderate, the Boreal Owl has extremely asymmetrical shape (Figure 3, 4).

The third analysis tried to describe the shape of the neurocranium in dorsal view. The first three PCs explained $49 \%, 24 \%$ and $12 \%$ of the variance in shape. The first PC axis described variation in the relative size and position (PC1) and the second reflected to the asymmetry of the otical region (PC2). The third PC axis described differences in the curvature of the occipital region (results not shown) (Figure 4). The analysis showed that Strix species differ considerably in their degree of asymmetry (Figure 6).

We tried to identify the differences between the diet categories (Figure 5). Larger species (Bubo bubo, Strix uralensis) are usually feeding primarily on vertebrates and having bigger beaks, lesser species (Athene noctua, Otus kennikotti) with smaller beaks feed more on smaller prey. 


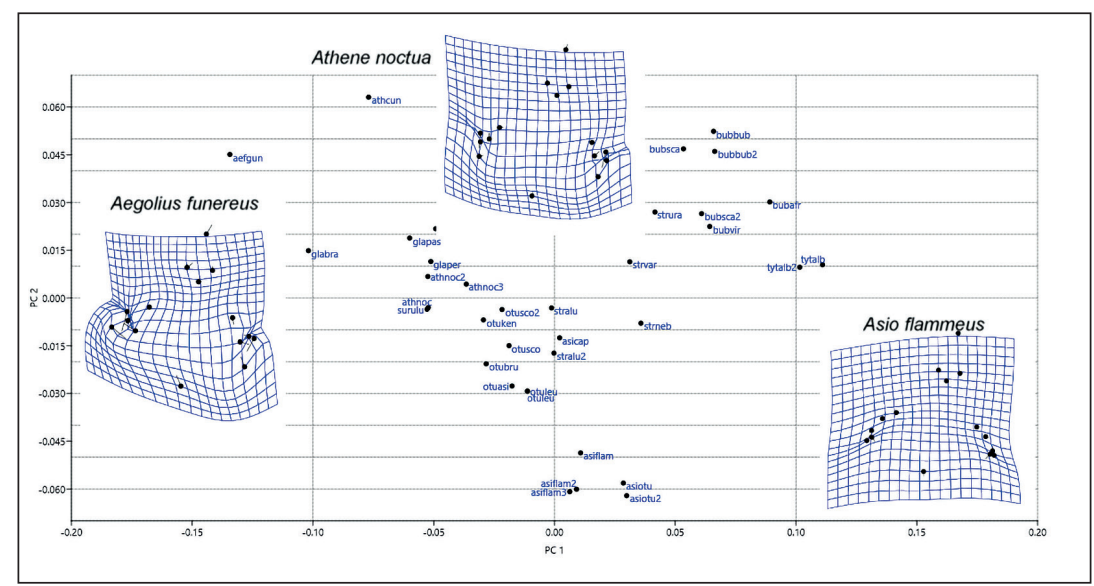

Figure 3. Graphical output of PCA performed on the two-dimensional landmark data (dorsal view). PC1PC2 biplot. PC axes described variation in the relative distances of the temporal wing (PC1), and the relative orientation at the tip (PC2) compared to the postorbital processes

3.ábra A PCA grafikus megjelenítése kétdimenziós landmark adatok alapján (felülnézet). Az első főtengely (PC1) a halántékcsont tympanicus nyúlványainak (TW) relatív távolságát, a második főtengely a processus postorbitalisok (POP) végeinek relatív helyzetét magyarázza

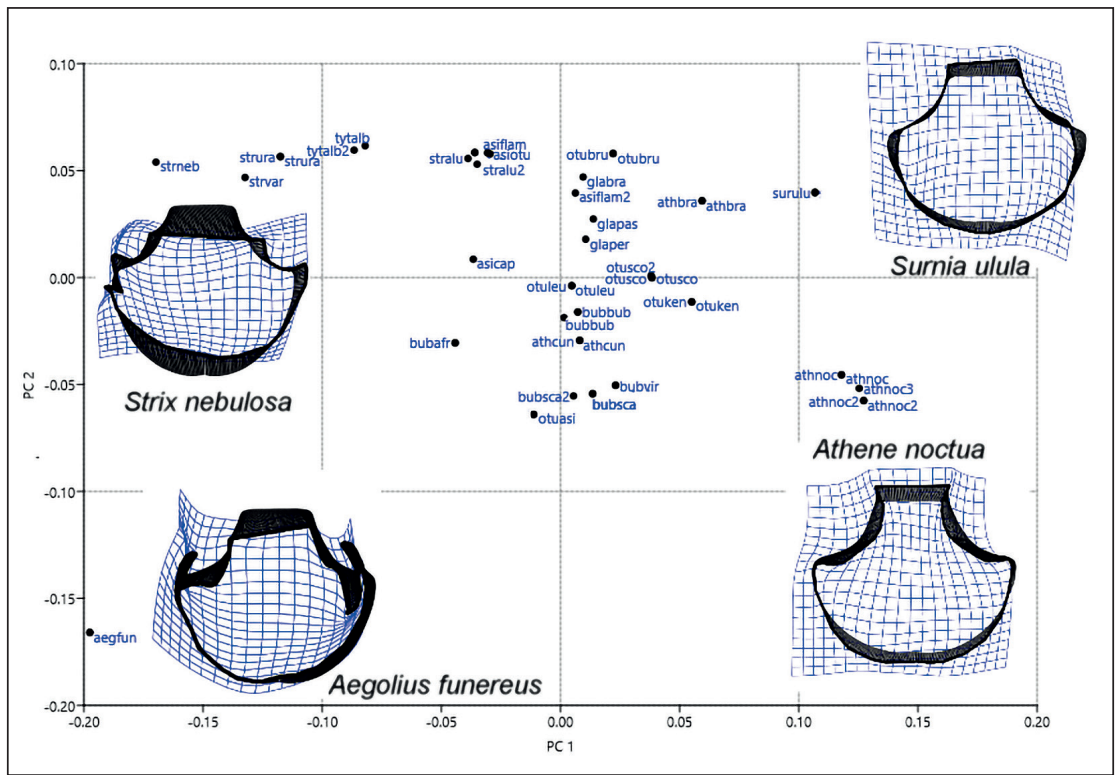

Figure 4. Graphical output of PCA performed on the two-dimensional landmark data (dorsal view). PC1PC2 biplot. This analysis tried to describe the shape of the neurocranium in dorsal view. PC axes described the variation in the relative size and position (PC1) and reflected to the asymmetry of the otical region (PC2). Thick black areas are showing the differences compared to the computer generated mean shape

4. ábra A PCA grafikus megjelenítése kétdimenziós landmark adatok alapján (felülnézet). A PC tengelyek az oticalis régió relatív nagyságát és helyzetét $(\mathrm{PC1}$ ) valamint annak aszimmetriája mértékét $(\mathrm{PC2})$ mutatják. A fekete vastagított terület a komputergenerált átlagformától való eltérést mutatja 


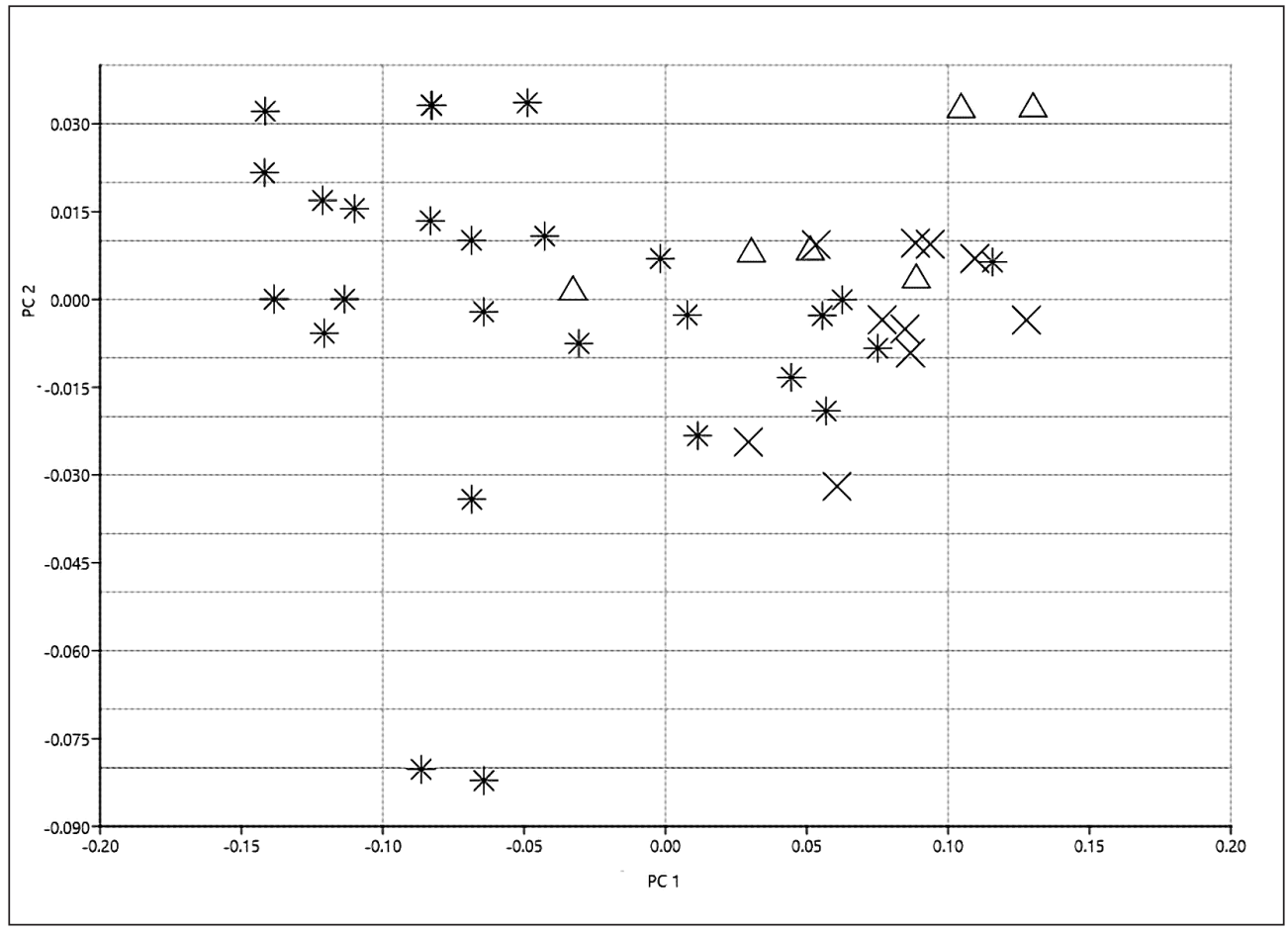

Figure 5. The species of different diet categories combined with the cranial shape in lateral view. X: feeds primarily on arthropods, $\Delta$ : species feed on arthropods and vertebrates, ${ }^{*}$ : feeds exclusively on vertebrates

5. ábra Kombinált ábra az egyes fajok oldalnézeti koponyaalakja és a táplálékbázisa alapján. X: elsődlegesen ízeltlábúakat fogyasztók, $\Delta$ : ízeltlábúakat és gerinceseket is fogyasztók, * : gerinceseket fogyasztók

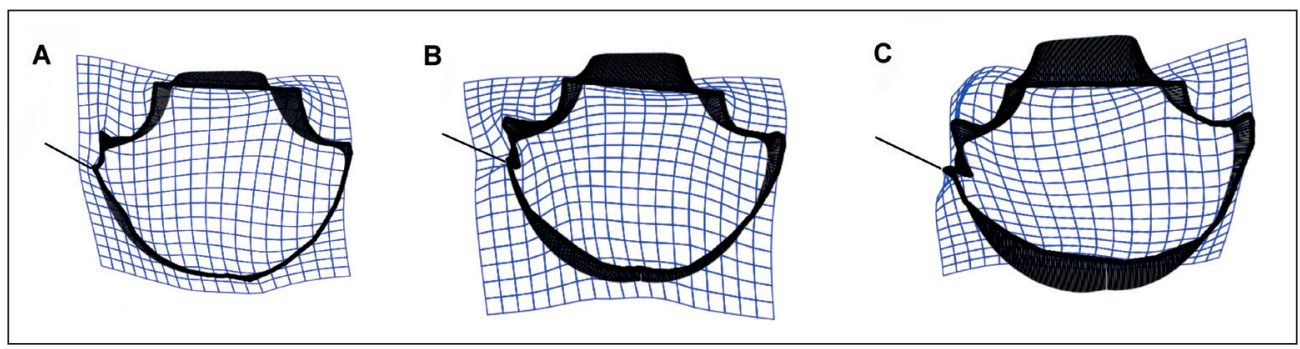

Figure 6. Various Strix species differ considerably in their degree of asymmetry. A: Tawny Owl (Strix aluco), B: Ural Owl (Strix uralensis), C: Great Grey Owl (Strix nebulosa)

6. ábra Az egyes Strix fajok különböznek az aszimmetria mértékében. A: Macskabagoly (Strix aluco), B: Uráli bagoly (Strix uralensis), C: Szakállas bagoly (Strix nebulosa) 


\section{Discussion}

We found that in the lateral view there are differences in the shape of the frontal and the occipital bone. The shape of the skull of Barn Owl was found to be markedly different from that other owl species, probably due to the phylogenetic distance. The main differences are in the relative height of the skull and the curvature of the frontal bone and the relative height and length of the beak. Owls swallow the prey animal whole but larger prey size demands stronger beaks and use their feet to tear apart their prey, then they swallow the pieces bit by bit. Larger species have longer beaks compared to the neurocranium. The allometric head growth reflected in variation in head length can explain some of the observed differences between various species because the smaller species usually have more paedomorphic attributes. Allometric patterns within populations do not necessarily parallel interspecific allometry (Grant et al. 1985). The skull of the owls is desmognathous and holorhinal, which means that the maxilla-palatine bones united and the anterior border of the nasal bones not deeply cleft. The occipital condyle is sessile and the plane of the occipital foramen looks directly downwards, forming a very oblique angle with the basicranial axis. In some species of eagle owls $(\mathrm{Bu}$ bo) the crest folded back upon itself into a narrow loop. The lambdoidal ridge well presented in eared owls (Asio), and the roof of the skull in most of the owls differs from the eared owls due to the excessive development of spongy pneumatic tissue (Pycraft 1902). The species of Asio have a very distinctive cranial morphology owing primarily to the large, semi-vertical, flattened surfaces of the cranium above and behind the orbits (Olson 1995). Possibly the dimensions of the lower jaw are showing that there are differences in bite performance between the species. Owls with symmetric skull structure may have stronger adductor muscles. Larger species are usually feeding exclusively or primarily on vertebrates, lesser species with smaller beaks feed more or only on arthropods. We found exceptions like the Boreal Owl (Aegolius funereus) and the Eurasian Pygmy Owl (Gaucidium passerinum).

The owls have generally good eyesight, which allows detecting the prey in low light and poor sighting conditions but these creatures are the most specialized birds for hearing. Many species are remarkable for the bilateral asymmetry of the ears. These attributes are linked to a highly developed sense of directional hearing (Coles et al. 1989). However, the differences are represented by different tissues of the head (feathers, earflaps, ear holes, etc.), ear asymmetry basically caused by cranial structures only, confined here the entirely to the different positions and orientations of the squamoso-occipital wing on both sides. Ear morphology is rather uniform among species but different in structure and geometry between groups. It is possible that the ear asymmetry has evolved independently at few times among owls (Norberg 1977). The symmetrical ears are representing a most basal form and cranial structure (Nishikawa 2002). Owls with asymmetrical ears can determine the horizontal and vertical direction of a sound, separately, since the time of arrival of the sound differ compare to the ears. This attribute allows localising the sound without head tilting (Newton 2002). A comparative study of location abilities between species with asymmetrical ears (Asio otus, Tyto alba) and symmetrical ears (Athene cunicularia, Bubo virginianus) has shown that the latter species accurate locate sources of sound in the horizontal plane only, while species with asymmetrical ears also localise sound vertically (Volman \& Konishi 1990). Symmetrical 
and relatively narrow earholes are present in Otus scops, Surnia ulula and Athene noctua (Voous 1988) and the asymmetry well presented by the species Tyto alba and Aegolis funereus (Norberg 1978, Nishikawa 2002). The great hearing abilities led the birds to be acoustic hunters. The birds with less sensitive hearing are using usually their eyes as visual hunters (Mikkola 2014).

Species with northern distribution should spend more time in darkness both daily and yearly, e.g. the Tawny Owl (Strix aluco), Ural Owl (Strix uralensis) (Goffette et al. 2016) and the Great Gray Owl (Strix nebulosa) (Del Hoyo et al. 1999, Mysterud 2016). Various Strix species differ considerably in their degree of asymmetry (Derlink et al. 2018). This suggests that selection pressure may differ among species, or may target different aspects of the hearing system. Modification of the tympanic wing affects the configuration of the temporal portion of the adductor muscles. The morphological change in the external ear and adductor muscle of owls are lesser known. Changes in the adductor muscle may be non-adaptive, and explainable mainly as side effects of evolutionary experimentation in the external ear (Holland 1993).

Species with large distribution, such as Barn Owl, have similar diet composition and similar preference in prey size in different regions. It was investigated in the Nearctic (Marti 1988, 2010) and Palearctic range (Bernard et al. 2010). Due to the similar prey consumption, differences in cranial morphology are not presented.

Future studies should further examine which proximate factors determine intraspecific and intersexual differences on skull (Tornberg et al. 2016). We can have the question, why species and subspecies differ in the degree of sexual dimorphism in different environments (McGillivray 1989). Due to the RSD, the females are usually larger than males, therefore their head is larger. Head size alone does not explain the sexual dimorphism in possibly different prey preference, assuming that other factors may be involved. Results suggest once more that foraging habits deserves closer attention. The dietary data also suggest strong implications for different prey preference in males. Male owls possibly eat smaller, softer, and less evasive prey than do females, and the electivity analyses implicate that they achieve this by actively selecting such prey types, and may thus potentially avoid competition of the males and females (Pérez-Camacho et al. 2015). In some cases, the similarities in the skull shape reflect the phylogenetic connection. In this study, we did not investigate the effect of phylogeny and the similarities due to phylogeny. The phylogenetic control would be necessary in further analyses.

\section{Acknowledgements}

We are grateful to Gábor Herczeg and János Török for their comments. We thank Péter Urtz, Ádám Pereszlényi and Mihály Gasparik for the technical assistance. Special thanks to Emese Bodor. The text was supervised by Bridgette Dreher. 


\section{References}

Andersson, M. 1994. Sexual Selection. - Princeton University Press, Princeton, NJ.

Baumel, J. J. 1993. Handbook of avian anatomy: Nomina Anatomica Avium. - Publications of the Nuttall Ornithological Club (USA). no. 23.

Bernard, N., Michelat, D., Raoul, F., Quéré, J-P., Delattre, P. \& Giraudoux, P. 2010. Dietary response of Barn Owls (Tyto alba) to large variations in populations of Common Voles (Microtus arvalis) and European Water Voles (Arvicola terrestris). - Canadian Journal of Zoology 88(4): 416-426. DOI: 10.1139/Z10-011

Brusatte, S. L., O'Connor, J. K. \& Jarvis, E. D. 2015. The origin and diversification of birds. - Current Biology 25(19): R888-R898. DOI: 10.1016/j.cub.2015.08.003

Cramp, S. 1978. The Birds of the Western Palearctic, Vol. 1. Ostrich to Ducks. - Oxford University Press, Oxford

Coles, R. B., Guppy, A., Anderson, M. E. \& Schlegel, P. 1989. Frequency sensitivity and directional hearing in the Gleaning Bat, Plecotus auritus (Linnaeus 1758). - Journal of Comparative Physiology A: Neuroethology, Sensory, Neural, and Behavioral Physiology 165(2): 269-280.

Colwell, R. K. 2000. Rensch's rule crosses the line: convergent allometry of sexual size dimorphism in hummingbirds and flower mites. - American Naturalist 156: 495-510. DOI: 10.1086/303406

Cracraft, J. 1981. Towards a phylogenetic classification of recent birds of the world (class Aves). - Auk 98: 681-714.

del Hoyo, J., Elliott, A. \& Sargatal, J. (eds.) 1999. Handbook of the Birds of the World, Vol. 5. Barn-owls to Hummingbirds. - Lynx Edicions, Barcelona

Derlink, M., Wernham, C., Bertoncelj, I., Kovács, A., Saurola, P., Duke, G. \& Vrezec, A. 2018. A review of raptor and owl monitoring activity across Europe: its implications for capacity building towards pan-European monitoring. - Bird Study DOI: 10.1080/00063657.2018.1447546

Dyson, M. L., Klump, G. M. \& Gauger, B. 1998. Absolute hearing thresholds and critical masking ratios in the European Barn Owl: a comparison with other owls. - Journal of Comparative Physiology A 182(5): 695-702.

Ericson, P. G. P., Anderson, C. L., Britton, T., Elzanowski, A., Johansson, U., Källersjö, M., Ohlson, J. I., Parsons, T. J., Zuccon, D. \& Mayr, G. 2006. Diversification of neoaves: integration of molecular sequence data and fossils. - Biological Letters 2: 543-547. DOI: 10.1098/rsbl.2006.0523

Feduccia, A. 1996. The origins and evolution of birds. - Yale University Press, New Haven

Galeotti, P. \& Sacchi, R. 2001. Turnover of territorial Scops Owls Otus scops as estimated by spectrographic analyses of male hoots. - Journal of Avian Biology 32(3): 256-262. DOI: 10.1111/j.0908-8857.2001.320308.x

Glue, D. \& Scott, D. 1980. Breeding biology of the Little Owl. - British Birds 73(1): 167-180.

Goffette, Q., Denis, M., Pöllath, N. \& Van Neer, W. 2016. Change in historical range of the Ural Owl in Europe. - Belgian Journal of Zoology 146(1): 33-43.

Grant, P. R., Abbott, I., Schluter, D., Curry, R. L. \& Abbott, L. K. 1985. Variation in the size and shape of Darwin's finches. - Biological Journal of the Linnean Society 25(1): 1-39. DOI: 10.1111/j.1095-8312.1985.tb00384.x

Hammer, Ø., Harper, D. A. T. \& Ryan P. D. 2001. PAST: paleontological statistics software package for education and data analysis. - Palaeontologia Electronica 4: 1-9.

Hámori, D., Winkler, D. \& Vadász, Cs. 2017. Demographic data on the Little Owl (Athene noctua) in Upper-Kiskunság (Hungary). - Ornis Hungarica 25(2): 11-22. DOI: 10.1515/orhu-2017-0012

Hackett, S. J., Kimball, R. T., Reddy, S., Bowie, R. C. K., Braun, E. L., Braun, M. J., Chojnowski, J. L., Cox, W. A., Han, K-L., Harshman, J., Huddleston, Ch. J., Marks, B. D., Miglia, K. J., Moore, W. S., Sheldon, F. H., Steadman, D. W., Witt, Ch. C. \& Yuri, T. 2008. A phylogenomic study of birds reveals their evolutionary history. - Science 320: 1763-1768. DOI: 10.1126/science.1157704

Holland, P. W. 1993. Avian skull. - In: Hanken, J. \& Hall, B. K. (eds.) The Skull, Vol. 2. Patterns of Structural and Systematic Diversity. - University of Chicago Press, Chicago

Horváth, A., Morvai, A. \& Horváth, G. F. 2018. Food-niche pattern of the Barn Owl (Tyto alba) in intensively cultivated agricultural landscape. - Ornis Hungarica 26(1): 27-40. DOI: 10.1515/orhu-2018-0002

Hounsome, T., O'Mahony, D. \& Delahay, R. 2004. The diet of Little Owls Athene noctua in Gloucestershire, England. - Bird Study 51(3): 282-284. DOI: 10.1080/00063650409461366

Kadochnikov, N. 1963. On the breeding biology of the Scops Owl in the Voronezh province. - Ornitologia 6: $104-110$.

Krüger, O. 2005. The evolution of reversed sexual size dimorphism in hawks, falcons and owls: a comparative study. - Evolutionary Ecology 19(5): 467-486. DOI: 10.1007/s10682-005-0293-9

Laursen, J. T. 1981. Prey of the Little Owl (Athene noctua), East Jutland (Denmark). - Danish Ornithological Society Magazine 75(3-4): 105-110. 
Lee, Y. F. \& Severinghaus, L. L. 2004. Sexual and seasonal differences in the diet of Lanyu Scops Owls based on fecal analysis. - Journal of Wildlife Management 68(2): 299-306. DOI: 10.2193/0022-541X(2004)068[0299:SASDIT]2.0.CO;2

Marti, C. D. 1988. A long-term study of food-niche dynamics in the Common Barn Owl: comparisons within and between populations. - Canadian Journal of Zoology 66(8): 1803-1812. DOI: 10.1139/z88-261

Marti, C. D. 2010. Dietary trends of Barn Owls in an agricultural ecosystem in Northern Utah. - Wilson Journal of Ornithology 122(1): 60-67. DOI: 10.1676/09-025.1

Mayr, E. \& Amadon, D. 1951. A classification of recent birds. - American Museum Novitates, American Museum of Natural History City of New York

McGillivray, W. B. 1989. Geographic variation in size and reverse size dimorphism of the Great Horned Owl in North America. - Condor 91(4): 777-786. DOI: 10.2307/1368060

Mikkola, H. 2014. Owls of the World - A Photographic Guide, $2^{\text {nd }}$ edition. - Firefly Books Ltd., Buffalo, New York

Milchev, B. 2015. Diet of Barn Owl Tyto alba in Central South Bulgaria as influenced by landscape structure. Turkish Journal of Zoology 39(5): 933-940. DOI: 10.3906/zoo-1409-24

Milchev, B. \& Spassov, N. 2017. First evidence for carrion-feeding of Eurasian Eagle-owl (Bubo bubo) in Bulgaria. - Ornis Hungarica 25(1): 58-69. DOI: 10.1515/orhu-2017-0005

Mueller, H. C. 1990. The evolution of reversed sexual dimorphism in size in monogamous species of birds. - Biological Reviews 65: 553-585. DOI: 10.1111/j.1469-185X.1990.tb01238.x

Mysterud, I. 2016. Range extensions of some boreal owl species: comments on snow cover, ice crusts, and climate change. - Arctic, Antarctic, and Alpine Research 48(1): 213-219. DOI: 10.1657/AAAR0015-041

Newton, I. (ed.) 2002. Ecology and conservation of owls. - Csiro Publishing, Collingwood, Victoria, Australia

Nishikawa, K. C. 2002. Evolutionary convergence in nervous systems: insights from comparative phylogenetic studies. - Brain, Behavior and Evolution 59(5-6): 240-249. DOI: 10.1159/000063561

Norberg, R. A. 1977. Occurrence and independent evolution of bilateral ear asymmetry in owls and implications on owl taxonomy. - Philosophical Transactions of the Royal Society of London B: Biological Sciences 280(973): 375-408. DOI: 10.1098/rstb.1977.0116

Norberg, R. Å. 1978. Skull asymmetry, ear structure and function, and auditory localization in Tengmalm's Owl, Aegolius funereus (Linné). - Philosophical Transactions of the Royal Society of London B: Biological Sciences 282(991): 325-410. DOI: 10.1098/rstb.1978.0014

Nybo, J. O. \& Sonerud, G. A. 1990. Seasonal changes in diet of Hawk Owls Surnia ulula: importance of snow cover. - Ornis Fennica 67: 45-51.

Olson, S. L. 1995. The genera of owls in the Asioninae. - Bulletin of the British Ornithologists' Club 115(1): 35-39.

Owens, I. P. F. \& Hartley, I. R. 1998. Sexual dimorphism in birds: why are there so many different forms of dimorphism? - Proceedings of the Royal Society B 265: 397-407. DOI: 10.1098/rspb.1998.0308

Papageorgiou, N. K., Vlachos, C. G. \& Bakaloudis, D. E. 1993. Diet and nest site characteristics of Eagle Owl (Bubo bubo) breeding in two different habitats in north-eastern Greece. - Avocetta 17(1): 49-54.

Pecsics, T., Laczi, M., Nagy, G. \& Csörgő, T. 2017. The cranial morphometrics of the wildfowl (Anatidae). - Ornis Hungarica 25(1): 44-57. DOI: 10.1515/orhu-2017-0004

Penteriani, V., Gallardo, M. \& Roche, P. 2002. Landscape structure and food supply affect Eagle Owl (Bubo bubo) density and breeding performance: a case of intra-population heterogeneity. - Journal of Zoology 257(3): 365-372. DOI: 10.1017/S0952836902000961

Pérez-Camacho, L., García-Salgado, G., Rebollo, S., Martínez-Hesterkamp, S. \& Fernández-Pereira, J. M. 2015. Higher reproductive success of small males and greater recruitment of large females may explain strong reversed sexual dimorphism (RSD) in the Northern Goshawk. - Oecologia 177(2): 379-387. DOI: 10.1007/ s00442-014-3146-9

Pycraft, W. P. 1902. Contributions to the osteology of birds. Part II. Strigiiformes. - Proceedings of the Zoological Society of London 20:1-46.

Rohlf, F. J. 2010. TpsDig, version 2.16. - Department of Ecology and Evolution, State University of New York, Stony Brook, USA

Šálek, M., Chrenkova, M. \& Kipson, M. 2013. High population density of Little Owl (Athene noctua) in Hortobagy National Park, Hungary, Central Europe. - Polish Journal of Ecology 61(1): 165-169.

Sibley, C. G. \& Ahlquist, J. E. 1990. Phylogeny and classification of birds: a study in molecular evolution. - Yale University Press 
Sonerud, G. A. 1986. Effect of snow cover on seasonal changes in diet, habitat, and regional distribution of raptors that prey on small mammals in boreal zones of Fennoscandia. - Ecography 9(1): 33-47. DOI: 10.1111/ j.1600-0587.1986.tb01189.x

Sonerud, G. A. 1992. Search tactics of a pause-travel predator: adaptive adjustments of perching times and move distances by Hawk Owls (Surnia ulula). - Behavioral Ecology and Sociobiology 30(3-4): 207-217.

Tornberg, R., Mikkola, H. \& Rytkönen, S. 2016. Morphometric sex determination of Great Grey Owls Strix nebulosa. - Ornis Norvegica 39: 6-10. DOI: 10.15845/on.v39i0.991

Uva, V., Päckert, M., Cibois, A., Fumagalli, L. \& Roulin, A. 2018. Comprehensive molecular phylogeny of barn owls and relatives (Family: Tytonidae), and their six major Pleistocene radiations. - Molecular Phylogenetics and Evolution 125: 127-137. DOI: 10.1016/j.ympev.2018.03.013

Verwaijen, D., Van Damme, R. \& Herrel, A. 2002. Relationships between head size, bite force, prey handling efficiency and diet in two sympatric lacertid lizards. - Functional Ecology 16(6): 842-850. DOI: 10.1046/j.13652435.2002.00696.x

Volman, S. F. \& Konishi, M. 1990. Comparative physiology of sound localization in four species of owls (Part 1 of 2). - Brain, Behavior and Evolution 36(4): 196-205. DOI: 10.1159/000115307

Voous, K. H. 1988. Owls of the Northern Hemisphere. - MIT Press, Cambridge, Massachusetts

Wink, M., Heidrich, P., Sauer-Gürth, H., El-Sayed, A-A. \& Gonzalez, J. M. 2008. Molecular phylogeny and systematics of owls (Strigiformes). - In: König, C. \& Weick, F. (eds.) Owls of the world, $2^{\text {nd }}$ edition. - Christopher Helm, London, pp. 42-63.

Wink, M., El-Sayed, A. A., Sauer-Gürth, H. \& Gonzalez, J. 2009. Molecular phylogeny of owls (Strigiformes) inferred from DNA sequences of the mitochondrial cytochrome b and the nuclear RAG-1 gene. - Ardea 97(4): 581-591. DOI: $10.5253 / 078.097 .0425$

Zelditch, M., Swiderski, D., Sheets, D. H. \& Fink, W. 2004. Geometric Morphometrics for Biologists: A primer: Elsevier Academic Press, Waltham, MA.

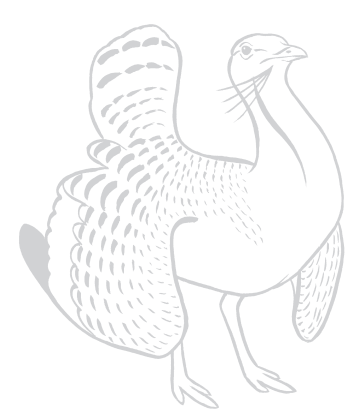

